\title{
Comparative study of three locally available feeds on the growth and nutritional quality of Oreochromis niloticus juveniles
}

\author{
Ella Pélagie Larissa Kouadio ${ }^{1}$, Ahou Rachel Koumi ${ }^{*}$, Tia Jean Gonnety ${ }^{1}$, Boua Célestin Atsé2 ${ }^{2}$ Lucien Patrice Kouamé ${ }^{1}$ \\ ${ }^{1}$ Université Nangui Abrogoua UNA, UFR des Sciences et Technologies des Aliments STA, Abidjan, Côte d’Ivoire \\ ${ }^{2}$ Département Aquaculture, Centre de Recherches Océanologiques CRO, Abidjan, Côte d'Ivoire
}

\section{ARTICLE INFO \\ Article history: \\ Received on: March 13, 2019 \\ Accepted on: July 04, 2019 \\ Available online: September 10, 2019}

Key words:

Agroecological areas,

Oreochromis niloticus, juveniles, feedstuffs, locally adapted feeds, growth

\begin{abstract}
The aim of the present study was to evaluate the effects of three feeds formulated for three fish farming agroecological areas of Côte d'Ivoire on the growth and nutritional quality of Oreochromis niloticus juveniles. Feeds were formulated at $30 \%$ crude protein with locally-sourced raw materials available by area. The use of different ingredients at different levels for feeds formulation made variations in the nutritional compositions and costs of the three feeds produced. The average male weight of $O$. niloticus juveniles, $26.89 \pm 2.98-27.35$ $\pm 2.74 \mathrm{~g}$, was stocked at a density of $3 \mathrm{fish} / \mathrm{m}^{2}$ and was hand fed at $5 \%-3 \%$ body weight two times daily, 6 days per week during 120 days in the triplicate earthen ponds. At the end of the feeding trial, daily weight gain values varied between $1.12 \pm 0.08 \mathrm{~g} /$ day and $1.21 \pm 0.06 \mathrm{~g} /$ day and survival rate ranged between $99.44 \pm 0.00$ and $100 \%$. No significant difference $(p<0.05)$ was observed in the growth performance and feed efficiency parameters of juveniles $O$. niloticus feeding. An increase in crude lipid and gross energy was observed in whole body compositions of $O$. niloticus feeding with the highest dietary lipid levels. Low-cost locally adapted feeds produced for $O$. niloticus juveniles growth were competitive and proffer the opportunity to improve availability of local quality feeds in the fish farming areas of Côte d'Ivoire.
\end{abstract}

\section{INTRODUCTION}

Fish is a major source of protein, essential fatty acids and micronutrients [1-3]. It contributes to the production of diversified and healthy diets. Hence, during the recent year around the world, aquacultural and fish production gained high increase to supply the fish needs of the populations [4]. In Côte d'Ivoire, most of the fish farming production is dominated by Nile tilapia Oreochromis niloticus [5]. This fish has been raised in Côte d'Ivoire since the year 1940 for subsistence or commercial purposes; and the vast majority of fish farmers use the semi-intensive system in the earthen pond as rearing structures for $O$. niloticus production [5-8]. However, tilapia $O$. niloticus rearing on the majority of Côte d'Ivoire fish farms in a semi-intensive system meet various difficulties. Some of these problems are a long time (9-12 months) of merchant $O$. niloticus production; low weight (250-350 g) of fish farming tilapia, as well

\footnotetext{
*Corresponding Author

Ahou Rachel Koumi, Centre de Recherches Océanologiques CRO,

Département Aquaculture, Abidjan, Côte d'Ivoire.

E-mail: koumirachel@yahoo.fr
}

as low yields $(1,000-6,000 \mathrm{~kg} / \mathrm{ha} /$ year $)$, recorded on the majority of fish farms reported by several authors [9-12]. Otherwise, the origins of these difficulties on the tilapia rearing are reported to be the inaccessibility of high-quality commercial feeds to the majority of fish farmers localized in the high concentration of fish farmers' areas who are usually low-income farmers [5]. This situation results to the strong use of non-quality feed sellers' commercial feeds; farm-made feeds; agro-industrial byproducts and non-conventional feeds to feed fish; non-respect of the feeding and rearing practices, thereby inducing low production of fish farming [11,12].

However, feeds are one of the major inputs in aquacultural production and the use of quality fish feeds in recommended quantity is the most important factor that determines the profitability and the sustainability of fish farms $[13,14]$. In the semi-intensive fish farming system, the tilapia merchant weight of $700 \mathrm{~g}$ and production yields of 15-17 tones/ha/year can be achieved with good nutrition practices $[11,15,16]$. According to Gabriel et al. [14] and Koumi et al. [8], the production of low-cost locally composed fish feeds, which take into account the requirement of different species and stages of farmed fish made with locally available raw 
materials with good processing methods, is the main challenge of fish farming. To try this solution, several authors tested with success the use of locally available ingredients in fish feeds [7,17-20].

In Côte d'Ivoire, the development of high-quality low-cost feeds for fish farmers has become a priority for many scientists. Previous works made by Bamba et al. [21,22] and Koumi et al. [23,24] on $O$. niloticus feeds, although based on local raw materials, were not specific to the areas of the high concentration of fish farmers. However, the different areas of fish farming practices in Côte d'Ivoire were well identified by [5] and availability and costs of raw materials vary by region and by area in the same country. In addition, the nutritional requirements of $O$. niloticus fingerlings are very well documented. The purpose of this study was to locally formulate low-cost quality feeds for $O$. niloticus juveniles in the three fish farming agroecological areas with accessible raw materials in each area to increase the availability of quality feeds for O. niloticus rearing in Côte d'Ivoire.

\section{MATERIALS AND METHODS}

\subsection{Agroecological Areas and Fish Farming Agroecological Areas}

According to MINESUDD [25], three agroecological areas (Guinean, Sudano-Guinean, and Sudanese) subdivided into four agroecological areas (Guinean, Sudano-Guinean I, SudanoGuinean II, and Sudanese) were identified in Côte d'Ivoire depending on climate, type of vegetation, rainfall and annual precipitation levels, altitude and agricultural crops. Table 1 presents the localization of the four agroecological areas in Côte d'Ivoire. Of the same, Figure 1 presents localization of fish farming practice in Côte d'Ivoire. Hence, Table 1 and Figure 1 show the practice of fish farming in Côte d'Ivoire only in the Guinean, Sudano-Guinean I, and Sudano-Guinean II areas in the South, West, Center, and East zones. Also, Yao et al. [5] reported a high concentration of fish farmers and/or high level of fish farming production in these three areas. In this study, feeds of $O$. niloticus juvenile stage were formulated and produced based on raw materials and feedstuffs accessible in Guinean, Sudano-Guinean I, and Sudano-Guinean II areas.

\subsection{Selection of Raw Materials and Feeds Formulation}

The raw materials used in the formulation of feeds were selected based on their availability, market prices, and nutritional values by three fish farming agroecological areas. But for the same nutritional quality of several raw materials, availability and prices were the definitive selection criteria. So low-cost local fish meal at $42 \%$ of protein $(0.52 \mathrm{USD} / \mathrm{kg})$, copra $(0.17 \mathrm{USD} / \mathrm{kg})$, white rice bran $(0.10 \mathrm{USD} / \mathrm{kg})$, and soybean meal $(0.70 \mathrm{USD} / \mathrm{kg})$ were selected for Guinean area feed formulation; imported fish meal (1.21 USD $/ \mathrm{kg})$ with $55 \%$ of protein content, white rice bran $(0.052$ $\mathrm{USD} / \mathrm{kg}$ ) and soybean meal (0.64 USD $/ \mathrm{kg})$ were used for SudanoGuinean area I; while local fish meal (0.52 USD $/ \mathrm{kg})$ content $42 \%$ protein, cottonseed oil cake (0.35 USD/kg), cornmeal (0.22 USD/ $\mathrm{kg})$, cashewnut oil cake $(0.35 \mathrm{USD} / \mathrm{kg})$, and soybean meal $(0.73$ $\mathrm{USD} / \mathrm{kg}$ ) were used for Sudano-Guinean area II feeds formulation (Table 2). Soybean meal available in the three agroecological areas and the two types of fish meals ( $42 \%$ and $55 \%$ of protein) were used as a protein source in feeds formulation (Table 3 ).

Table 1: Côte d'Ivoire agroecological areas [25]

\begin{tabular}{|c|c|c|c|}
\hline Agroecological areas & Regions & Zones & Departments and subprefectures \\
\hline Guinean & $\begin{array}{l}\text { Agnéby-Tiassa, } \\
\text { Grands-Ponts, } \\
\text { La Mé } \\
\text { Sud-Comoé } \\
\text { Nawa, } \\
\text { Haut Sassandra } \\
\text { Loh Djiboua, } \\
\text { Tonkpi, } \\
\text { Guemon, } \\
\text { San-Pedro, } \\
\text { Gbôkè }\end{array}$ & $\begin{array}{l}\text { South and West of the } \\
\text { country }\end{array}$ & $\begin{array}{l}\text { Agboville, Tiassalé, Taabo, Sikensi, Rubino, Azaguié, Dabou, Grand-Lahou, Jacqueville, Adzopé, } \\
\text { Akoupé, Alépé, Yakasse-Attobrou, Affery, Agou, Aboisso, Adiake, Ayame, Grand-Bassam, Bonoua, } \\
\text { Tiapoum, Maféré; San-Pedro, Tabou, Gbôklè, Sassandra, Fresco, Nawa, Soubré, Buyo, Guéyo, Méagui, } \\
\text { Daloa, Gonaté, Domangbeu, Issia, Nahio, Vavoua, Bazra-Nattis, Ketro-Bassam, Séitifla, Gadouan, } \\
\text { Zaibo, Bediala, Boguhé, Zoukougbeu, Divo, Didoko, Gbagam, Lauzoua, Ogoudou, Dairo-Didizo, } \\
\text { Guitry, Lakota, Goudouko, Zikisso, Djidji, Man, Logoualé, Podiagouiné, Yapleu, Duekoué, Facobly, } \\
\text { Kouibly, Totrodrou, Sémien, Danané, Daleu, Kouan-Houlé, Mahapleu, Bangolo, Zéo, Diéouzon, Zou, } \\
\text { Biankouma, Santa, Zouan-Hounien, Banneu, Teapleu }\end{array}$ \\
\hline Sudano-Guinean I & $\begin{array}{l}\text { Gôh } \\
\text { Marahoué } \\
\text { Indenié-Djuablin, } \\
\text { Moronou, } \\
\text { N'zi, } \\
\text { Guemon, } \\
\text { Bafing, } \\
\text { Cavally }\end{array}$ & $\begin{array}{l}\text { South-Central of the } \\
\text { country }\end{array}$ & $\begin{array}{l}\text { Gagnoa, Guibéroua, Ouragahio, Gnagbodougnoa, Dignago, Bayota, Doubé, Galebouo, Serihio, Oumé, } \\
\text { Guepahouo, Tonla, Diégonéfla, Bouaflé, Sinfra, Zuénoula, Gohitafla, Bonon, Abengourou, Niablé } \\
\text { et Agnibilékrou, Dimbokro, Bongouanou, Arrah, Tiémélékro, Kotobi, Guiglo, Zagné, Nizahon, Taï, } \\
\text { Duékoué, Toulepleu, Blolequin, Zéaglo, Touba, Koro, Ouaninou }\end{array}$ \\
\hline Sudano-Guinean II & $\begin{array}{l}\text { Gbeke, } \\
\text { District de Yamoussoukro, } \\
\text { Iffou, } \\
\text { Bounkani, Worodougou, } \\
\text { Belier } \\
\text { Gontougo }\end{array}$ & $\begin{array}{l}\text { Central and East of } \\
\text { Country }\end{array}$ & $\begin{array}{l}\text { Bouaké, Béoumi, Dabakala, Katiola, Fronan, Niakaramandougou, Tafiré, Tortiya, Sakassou, Botro, } \\
\text { Yamoussoukro, Toumodi, Kossou, Tiébissou, Yakpabo-Sakassou, Molonou, Lomokankro, Didiévi, } \\
\text { Molonou-Blé, Prikro, Ouellé, M’Bahiakro, Daoukro, Bocanda, Bouna, Doropo, Nassian, Tehini, } \\
\text { Bondoukou, Koun-Fao, Sandegue, Tanda, Transua, Séguéla, Massala, Maradiassa }\end{array}$ \\
\hline Sudanese & $\begin{array}{l}\text { Poro, } \\
\text { Bagoué, } \\
\text { Tchologo, } \\
\text { Hambol, } \\
\text { Folon, } \\
\text { Kabadougou }\end{array}$ & North of Country & $\begin{array}{l}\text { Korhogo, Sirasso, Niofoin, Boron, Kanoroba, Sinématiali, Boundiali, Ganaoni, Kasséré, Siempurgo, } \\
\text { Kouto, Blességué, Gbon, Kolia, Sianhala, Ferkessédougou, Togoniéré, Ouangolodougou, Tingréla, } \\
\text { Kanakono, Folon, Minignan, Sokoro, Tienko, Kimbirila Nord, Kaniasso, Goulia, Mahandiana- } \\
\text { Sokourani, Kabadougou, Samatiguila, Kimbirila Sud, Odienné, Samango, Gbéléban, Seydougou, } \\
\text { Bougousso, Bako, Dioulatiédougou, Tiémé, Madinani, Fengolo, N'Goloblasso, Séguélon, Gbongaha }\end{array}$ \\
\hline
\end{tabular}


White rice bran was used as a major source of carbohydrate in the Guinean and Sudano-Guinean I areas, and cornmeal was used as carbohydrate source of feed in the Sudano-Guinean I. Three isonitrogenous $30 \%$ protein feeds were formulated using linear programming method to quantify the different raw materials by feed (Table 4). All feedstuffs were incorporated following the limit levels recommended for fish feeds. Then, for each formulation, dry feed ingredients were weighed, ground in fine flour, and mixed and mixes were pelleted in 2-mm diameter pellets. Feeds were produced in bimonthly frequency to cover the needs of fish feeding. Samples of all the feeds produced were collected to the complete nutritional quality and analyzed according to [26,27].

\subsection{Fish and Feeding Trial}

Juveniles males of tilapia $O$. niloticus were collected from a private fish farmer near Azaguié town (Latitude $5^{\circ}-6^{\circ}$ North; Longitude $4^{\circ}-5^{\circ}$ West) to constitute the three different groups of feeding trial. Three replicate earthen ponds were used by the feed formulated and feeding trial was performed on one fish farm located near Azaguié town, in Agboville Department localized in the south of

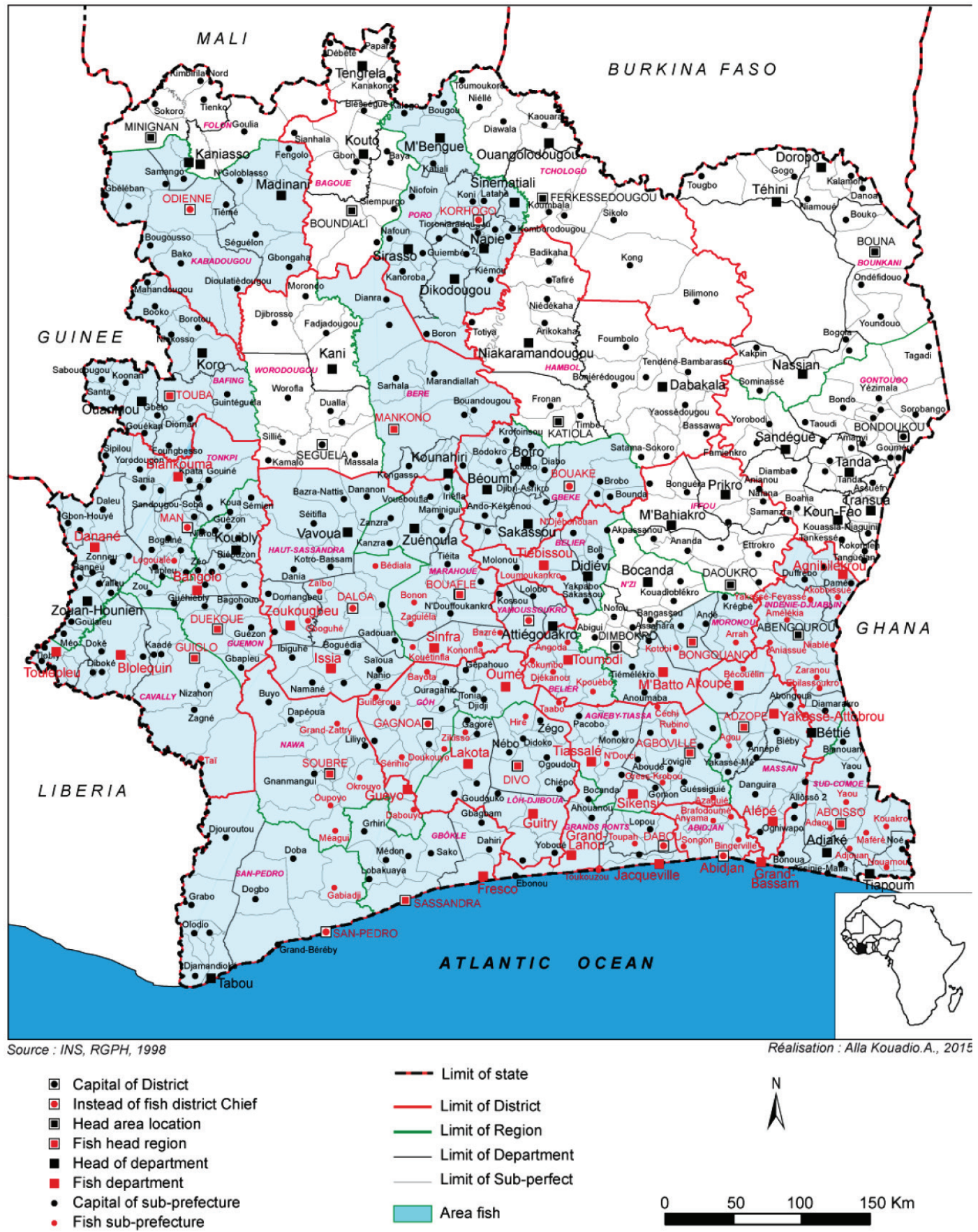

Figure 1: Districts, Regions, Departments, and Subprefectures of fish farming practice in Côte d'Ivoire according to Yao et al. [5]. 
Côte d'Ivoire to $40 \mathrm{~km}$ near Abidjan. Rearing was realized in the same conditions of fish farmers. Juveniles Nile tilapia $O$. niloticus of an average weight of $26.89 \pm 2.98-27.35 \pm 2.74 \mathrm{~g}$ were stocked at a density of 3 fish per square-meter and were hand-fed at 3\%5\% body weight two times daily at 09:00 and 17:00 hours 6 days per week during 120 days. Earthen ponds water temperature, $\mathrm{pH}$, dissolved oxygen, Total Dissolved Solids (TDS), Potential redox (ORP), and conductivity were monitored throughout the feeding trial. These parameters were measured weekly using multiparameter HANNA type. Every month, a sample of $30 \%$ fish was collected by the pond, individually weighed and measured. Then the monthly fish biomass by the pond was calculated based on the fish mean weight and the number of fish death recorded during the month for adjusting the feeding ration. At the end of the feeding trial, fish of each pond were harvested, counted, and individually weighed and measured. Total quantity of feed used was calculated for each pond.

\subsection{Determination of Growth and Feed Efficiency Parameters}

Growth and feed utilization parameters were calculated using the following formulas according to [28]:

Weight gain: WG $(\mathrm{g})$

$W G(g)=$ Final body weight of fish - Initial body weight of fish

Length gain: LG $(\mathrm{cm})$

$L G(\mathrm{~cm})=$ Final fish lenght - Initial fish lenght

Table 2: Variation of the market price of raw materials selected by agroecological area.

\begin{tabular}{|c|c|c|c|}
\hline \multirow[b]{2}{*}{ Raw materials } & \multicolumn{3}{|c|}{ Price (USD/kg)* } \\
\hline & Guinean Area & $\begin{array}{c}\text { Sudano-Guinean } \\
\text { area I }\end{array}$ & $\begin{array}{c}\text { Sudano-Guinean } \\
\text { area II }\end{array}$ \\
\hline Fish meal (55) & 1.11 & 1.21 & 1.21 \\
\hline Fish meal (42) & 0.52 & 0.52 & 0.52 \\
\hline Soybean meal & 0.70 & 0.64 & 0.73 \\
\hline Cottonseed oil cake & 0.41 & 0.37 & 0.35 \\
\hline Cashewnut oil cake & 0.35 & - & 0.35 \\
\hline Copra & 0.17 & 0.27 & 0.22 \\
\hline White rice bran & 0.10 & 0.052 & - \\
\hline Cornmeal & 0.28 & 0.26 & 0.22 \\
\hline
\end{tabular}

$* 1$ USD $=578.54$ FCFA based on February 2019 exchange data
Daily Weight Gain: DWG (g/day)

$$
D W G(g / \text { day })=\frac{\text { Final weight of fish }- \text { Initial weight of fish }}{\text { Number of trial days }}
$$

Daily Length Gain: DLG (cm/day)

$$
D L G(\mathrm{~cm})=\frac{\text { Final fish length }- \text { Initial fish length }}{\text { Number of trial days }}
$$

Specific Growth Rate: SGR (\%/day)

$S G R(\% /$ day $)=\frac{\text { Ln }(\text { Final weight of fish })-\text { Ln }(\text { Initial weight of fish })}{\text { Number of trial days }} \times 100$

Survival Rate: SR (\%)

$$
S R(\%)=\frac{\text { Final number of fish }- \text { Initial number of fish }}{\text { Initial number of fish }} \times 100
$$

Feed Conversion Ratio: FCR

$$
F C R=\frac{\text { Total weight of feed consumed by fish }}{\text { Wet fish biomass gain }}
$$

Protein Efficiency Ratio: PER

$$
P E R=\frac{\text { Wet fish biomass gain }}{\text { Total dietary protein in take }}
$$

Table 4: Formulation $(\mathrm{kg} / 100 \mathrm{~kg})$ and costs of feeds produced for O. niloticus

\begin{tabular}{|c|c|c|c|c|c|c|c|c|}
\hline & Fish meal (55) & Fish meal (42) & Soybean meal & Cottonseed oil cake & Cashewnut oil cake & Copra & White rice bran & Cornmeal \\
\hline Moisture (\%) & $11.23 \pm 21$ & $8.92 \pm 0.56$ & $11.89 \pm 0.50$ & $9.66 \pm 0.51$ & $6.14 \pm 0.51$ & $8.63 \pm 0.57$ & $9.88 \pm 0.22$ & $12.68 \pm 0.81$ \\
\hline Crude protein $(\%)$ & $55.30 \pm 0.12$ & $42.67 \pm 1.00$ & $44.56 \pm 2.29$ & $35.71 \pm 0.73$ & $19.87 \pm 1.74$ & $19.67 \pm 0.57$ & $11.95 \pm 1.77$ & $5.77 \pm 0.37$ \\
\hline Crude lipid (\%) & $9.05 \pm 0.71$ & $14.59 \pm 0.88$ & $1.74 \pm 0.51$ & $3.01 \pm 0.10$ & $38.90 \pm 0.36$ & $16.02 \pm 0.64$ & $14.27 \pm 1.76$ & $4.38 \pm 0.37$ \\
\hline Ash (\%) & $21.15 \pm 0.98$ & $29.17 \pm 0.12$ & $6.09 \pm 0.16$ & $5.93 \pm 1.46$ & $3.21 \pm 0.18$ & $5.73 \pm 0.40$ & $8.75 \pm 1.05$ & $1.87 \pm 0.95$ \\
\hline Crude fiber (\%) & $2.39 \pm 0.61$ & $4.84 \pm 0.83$ & $4.67 \pm 0.40$ & $24.58 \pm 0.25$ & $6.08 \pm 0.32$ & $34.58 \pm 3.11$ & $10.37 \pm 0.28$ & $2.91 \pm 0.04$ \\
\hline $\mathrm{NFE}^{1}(\%)$ & $0.99 \pm 0.46$ & $0.51 \pm 0.40$ & $31.32 \pm 3.27$ & $21.10 \pm 1.79$ & $26.73 \pm 1.23$ & $15.13 \pm 0.98$ & $44.68 \pm 2.67$ & $71.97 \pm 0.52$ \\
\hline Calcium (mg/g) & 57.90 & 65.37 & 3.48 & 1.10 & 0.17 & 1.23 & 0.97 & 0.23 \\
\hline Phosphorus (mg/g) & 26.00 & 28.90 & 3.14 & 4.88 & 1.53 & 5.30 & 7.78 & 2.53 \\
\hline
\end{tabular}
juveniles rearing by agroecological area $(\mathrm{G}=$ Guinean zone; Sudano-Guinean area $\mathrm{I}=$ SGI; Sudano-Guinean area II = SGII).

\begin{tabular}{lccc} 
Parameters & G-30\% & $\begin{array}{c}\text { Fish feeds } \\
\text { SGI-30\% }\end{array}$ & SGII-30\% \\
Raw materials & - & 20 & - \\
Fish meal (55) & 30 & - & 25 \\
Fish meal (42) & 10 & - & - \\
Copra & - & - & 20 \\
Cottonseed oil cake & - & - & 20 \\
Cornmeal & 25 & 45 & - \\
White rice bran & - & - & 10 \\
Cashewnut oil cake & 35 & 35 & 25 \\
Soybean meal & 100 & 100 & 100 \\
Total (kg) & 0.43 & 0.52 & 0.49 \\
Cost (USD/kg) & & & \\
\hline
\end{tabular}

Table 3: Variation of proximate composition of raw materials selected by agroecological area.

${ }^{1}$ Nitrogen Free Extract $=100-($ moisture + crude protein + crude lipid + crude fiber + ash $)$. 


\subsection{Proximate Composition Analysis of Feeds and Fish}

Proximate composition of fish and feeds was determined according to $[26,27]$. Dry matter (DM) was determined after drying the samples in an oven $\left(80^{\circ} \mathrm{C}\right)$ until a constant mass. Crude protein was measured using Kjeldhal method $(N \% \times 6.25)$, Ash was measured by incineration at $550^{\circ} \mathrm{C}$ in a muffle furnace for 24 hours, and crude fat was determined using Soxhlet extraction with hexane as solvent. The gross energy content of feeds and fish samples were calculated based on energy equivalents of crude protein, crude fat, and total carbohydrates; 23.7, 39.5, and 17.2 $\mathrm{kJ} / \mathrm{g}$, respectively [29]. The mineral contents of the samples were determined by atomic absorption spectrophotometer. All analyses were made in triplicate for each sample.

\subsection{Statistical Analysis}

Statistical analysis of data collected was performed on STATISTICA 7.1 software. Data were expressed as means \pm standard deviation. One-way ANOVA analysis of variance was used to compare the values. Then, Duncan multiple range tests were used to compare differences among means. Differences were considered significant at $p<0.05$.

\section{RESULTS}

\subsection{Fish Feeds}

Proximate and mineral composition of feeds produced for $O$. niloticus juveniles by agroecological area are shown in Table 5. All feeds were isoproteic at 30\% protein level without any significant difference between feeds. However, significant differences were recorded at $p<0.05$ for all the other biochemical parameters (moisture, crude lipid, crude fiber, ash, carbohydrate, gross energy, and protein/energy) determined. The high values of moisture were recorded with feeds SGI-30\% $(8.50 \% \pm 0.08 \%)$ and SGII-30\% $(8.10 \% \pm 0.04 \%)$; feeds G-30\% $(5.35 \% \pm 0.11 \%)$ and SGII-30\% $(5.00 \% \pm 0.04 \%)$ presented the highest values of crude fiber; highest values of gross energy were recorded with feeds SGI-30\% $(18.35 \pm 0.04 \mathrm{~kJ} / \mathrm{g})$ and SGII-30\% $(17.81 \pm 0.16 \mathrm{~kJ} / \mathrm{g})$ when G-30\% (17.73 $\pm 0.09 \mathrm{mg} / \mathrm{kJ})$ and SGII-30\% (17.32 \pm 0.09 $\mathrm{mg} / \mathrm{kJ}$ ) showed the highest values of protein/energy ratio. Feed SGI-30\% recorded significantly $(p<0.05)$ highest values of crude lipid $(11.02 \% \pm 0.02 \%)$ and carbohydrate $(35.24 \% \pm 0.14 \%)$, followed by feed SGII-30\% (10.20\% $\pm 0.08 \% ; 32.62 \% \pm 0.17 \%)$, while feed G-30\% $(9.93 \% \pm 0.07 \% ; 29.22 \% \pm 0.14 \%)$ recorded the lowest values of these two parameters. Inversely, feed G-30\% presented significantly $(p<0.05)$ highest values of ash $(18.62 \%$ $\pm 0.09 \%)$, followed by SGII-30\% $(13.25 \% \pm 0.10 \%)$, while feed SGII-30\% recorded lowest values $(10.62 \% \pm 0.03 \%)$. Calcium and phosphorus values of the three feeds formulated ranged between 5.10 and $9.37 \mathrm{mg} / \mathrm{g}$ and 14.15 and $18.25 \mathrm{mg} / \mathrm{g}$, respectively.

\subsection{Water Quality}

Water quality parameters values in ponds during the feeding trial are presented in Table 6. No significant difference $(p>0.05)$ was recorded between all the water physicochemical parameters values recorded. Temperature means values ranged between $29.58 \pm 1.22(\mathrm{G}-30 \%)$ and $29.92 \pm 1.14^{\circ} \mathrm{C}(\mathrm{SGI}-30 \%)$, $\mathrm{pH}$ values varied between $8.92 \pm 0.88$ (G-30\%) and 9.62 \pm 0.74 (SGII-30\%), dissolved oxygen and \% dissolved oxygen ranged, respectively, within $8.05 \pm 1.07$ (SGI-30\%)-8.25 $\pm 1.56 \mathrm{mg} / \mathrm{L}$ (SGII-30\%) and $102.83 \pm 18.49$ (G-30\%)-102.83 \pm 18.49 (SGI-30\%). Conductivity varied between $19.43 \pm 7.50$ and $20.00 \pm 8.49 \mu \mathrm{s} /$ $\mathrm{cm}$, while ORP values fluctuated between $47.6 \pm 8.29$ (SGII-30\%) and $54.94 \pm 6.46 \mathrm{mV}$ (SGI-30\%). Water salinity values recorded in ponds were zero.

\subsection{Fish Growth and Feed Efficiency}

Growth of $O$. niloticus juveniles fed with the different feeds is shown in Figure 2. Similar growth evolution trends were observed with the three groups of fish fed. Also, there was no significant difference $(p>0.05)$ in the monthly growth of the three groups of fish during the feeding trial. At the end of the growth trial, similar significant $(p>0.05)$ results were observed with all the parameters of growth performance and feed efficiency of $O$. niloticus juveniles analyzed. No significant difference was observed $(p>0.05)$ between all these parameters despite the differences observed between the means of values recorded (Table 7). Means weight gain values recorded for the three groups

Table 5: Proximate and mineral composition of feeds produced for $O$. niloticus juveniles rearing by agroecological area $(\mathrm{G}=$ Guinean area; Sudano-Guinean area I = SGI; Sudano-Guinean area II = SGII).

\begin{tabular}{lccc} 
Parameters & \multicolumn{3}{c}{ Fish feeds } \\
& G-30\% & SGI-30\% & SGII-30\% \\
\hline Moisture (\%) & $6.70 \pm 0.04^{\mathrm{a}}$ & $8.50 \pm 0.08^{\mathrm{b}}$ & $8.10 \pm 0.04^{\mathrm{b}}$ \\
Crude protein (\%) & $30.19 \pm 0.09^{\mathrm{a}}$ & $30.97 \pm 0.03^{\mathrm{a}}$ & $30.84 \pm 0.10^{\mathrm{a}}$ \\
Crude lipid (\%) & $9.93 \pm 0.07^{\mathrm{a}}$ & $11.02 \pm 0.02^{\mathrm{c}}$ & $10.20 \pm 0.08^{\mathrm{b}}$ \\
Crude fiber (\%) & $5.35 \pm 0.11^{\mathrm{b}}$ & $4.15 \pm 0.04^{\mathrm{a}}$ & $5.00 \pm 0.04^{\mathrm{b}}$ \\
Ash (\%) & $18.62 \pm 0.09^{\mathrm{c}}$ & $10.62 \pm 0.03^{\mathrm{a}}$ & $13.25 \pm 0.10^{\mathrm{b}}$ \\
Carbohydrate (\%) & $29.22 \pm 0.14^{\mathrm{a}}$ & $35.24 \pm 0.14^{\mathrm{c}}$ & $32.62 \pm 0.17^{\mathrm{b}}$ \\
Gross energy (kJ/g) & $17.02 \pm 0.07^{\mathrm{a}}$ & $18.35 \pm 0.04^{\mathrm{b}}$ & $17.81 \pm 0.16^{\mathrm{ab}}$ \\
Protein/energy (mg/kJ) & $17.73 \pm 0.09^{\mathrm{b}}$ & $16.61 \pm 0.05^{\mathrm{a}}$ & $17.32 \pm 0.09^{\mathrm{ab}}$ \\
Calcium (mg/g) & 9.37 & 5.10 & 8.86 \\
Phosphorus (mg/g) & 18.25 & 14.15 & 14.82 \\
\hline
\end{tabular}

a, b, calphabetical letters on the same line show a significant difference among treatments at $p<0.05$.

Table 6: Physicochemical parameters values of the water in ponds during the feeding trial.

\begin{tabular}{lccc} 
Parameters & \multicolumn{3}{c}{ Fish feeds } \\
Temperature $\left({ }^{\circ} \mathrm{C}\right)$ & $29.58 \pm 1.22^{\mathrm{a}}$ & $29.92 \pm 1.14^{\mathrm{a}}$ & $29.79 \pm 1.21^{\mathrm{a}}$ \\
$\mathrm{pH}$ & $8.92 \pm 0.88^{\mathrm{a}}$ & $8.95 \pm 0.86^{\mathrm{a}}$ & $9.62 \pm 0.74^{\mathrm{a}}$ \\
Dissolved oxygen $(\mathrm{mg} / \mathrm{L})$ & $8.15 \pm 0.64^{\mathrm{a}}$ & $8.05 \pm 1.07^{\mathrm{a}}$ & $8.25 \pm 1.56^{\mathrm{a}}$ \\
\% dissolved oxygen & $106.19 \pm 11.67^{\mathrm{a}}$ & $102.83 \pm 18.49^{\mathrm{a}}$ & $106.02 \pm 16.77^{\mathrm{a}}$ \\
Conductivity $(\mu \mathrm{s} / \mathrm{cm})$ & $19.43 \pm 7.50^{\mathrm{a}}$ & $20.00 \pm 6.07^{\mathrm{a}}$ & $20.00 \pm 8.49^{\mathrm{a}}$ \\
TDS $(\mathrm{mg} / \mathrm{L})$ & $10.01 \pm 3.83^{\mathrm{a}}$ & $10.50 \pm 4.89^{\mathrm{a}}$ & $9.33 \pm 3.01^{\mathrm{a}}$ \\
ORP $(\mathrm{mV})$ & $51.51 \pm 10.36^{\mathrm{a}}$ & $54.94 \pm 6.46^{\mathrm{a}}$ & $47.6 \pm 8.29^{\mathrm{a}}$ \\
Salinity & $0^{\mathrm{a}}$ & $0^{\mathrm{a}}$ & $0^{\mathrm{a}}$ \\
\hline a, b,calphabetical letters on the same line show a significant difference among treatments at $p<0.05$.
\end{tabular}


of $O$. niloticus fed with feeds produced varied between $134.62 \pm$ 9.63 (SGII-30\%) and $144.89 \pm 7.25 \mathrm{~g}(\mathrm{G}-30 \%)$ with daily weight gain oscillated between $1.12 \pm 0.08$ (SGII-30\%) and $1.21 \pm 0.06 \mathrm{~g} /$ day (G-30\%). Survival rate recorded ranged between $99.44 \pm 0.00$ (SGII-30\%) and 100\% (G-30\%; SGI-30\%). Feed conversion ratio values oscillated between $2.85 \pm 0.14(\mathrm{G}-30 \%)$ and $2.88 \pm 0.21$ (SGII-30\%) when protein efficiency ratio varied between $1.13 \pm$ 0.08 (SGII-30\%) and $1.17 \pm 0.08$ (G-30\%).

\subsection{Proximate Composition of Juveniles $O$. niloticus}

Whole body composition data of juveniles $O$. niloticus fed with feeds produced by fish farming agroecological area during 4 months are shown in Table 8. No significant difference $(p<0.05)$ was found between the crude protein and ash content of three fish groups. Protein content varied between $19.83 \pm 1.0$ (SGI-30\%) and $20.78 \% \pm 1.00 \%$ (SGII-30\%); and Ash values ranged between $1.09 \pm 0.15$ (G-30\%) and $1.19 \% \pm 0.01 \%$ (SGI-30\%). Significantly highest $(p<0.05)$ values of fish moisture content was recorded with fish fed with feeds G-30\% (77.35 $\pm 0.42 \%)$ and SGI-30\% $(76.73 \% \pm 0.64 \%)$, highest lipid content was observed with fish fed with feed SGII-30\% $(2.62 \% \pm 0.17 \%)$, followed by those of fish fed with feed SGI-30\% $(1.85 \% \pm 0.06 \%)$, and fish fed with feed $\mathrm{G}-30 \%(0.96 \% \pm 0.13 \%)$ presented the lowest values. The same trend was observed with fish gross energy values recorded which were highest from fish fed with feed SGII-30\% (5.96 \pm $0.23)$ and lowest from fish fed with feed G-30\% $(5.18 \pm 0.06)$.

\section{DISCUSSION}

All fish feeds produced were isoproteic at 30\% protein level, but the difference between the compositions of feeds formulated depending on the availability, the cost, and the nutritional values of raw material used by area induced variations in feeds proximate composition. Using the fish meal, $42 \%$ protein at $30 \%$ in fish feed G-30\% consequently influenced this feed moisture and carbohydrate levels and increased its ash, calcium, and phosphorus level compared to the other two feeds. High level of ash in fish meal used in feeds formulation influences the ash and mineral levels of the feed [29]. However, an excess of minerals and ash in fish feeds compared to the requirement value $(<10)$ could be well released into the water by fish and should not affect the uptake of the other nutrient of feeds as reported by [29,30]. Also, high level of white rice bran incorporated in feed SGI-30\% and the use of cashewnut oil cake in feed SGII-30\%, both rich in the lipid at, respectively, $10.37 \%$ and $38.90 \%$, consequently increased the levels of these feeds in lipid, carbohydrate, and gross energy compared to feeds G-30\%. However, all feeds produced follow the needs of $30 \%-$ $35 \%$ protein, $6 \%-10 \%$ lipid, inferior to $8 \%-10 \%$ fiber, and the minimum of $25 \%$ carbohydrate required for good growth of this stage (10-35 g) of $O$. niloticus juveniles reported by [31]. Also, the difference in price and quantity from the ingredients used for the three feeds formulated affected their cost. The lowest cost of feed recorded by feed G-30\% could be due to the incorporating of $30 \%$ level of the low-cost local fish meal at $42 \%$ of protein, the good accessibility of copra, white rice bran and soybean meal in Guinean area, and its high level of industrialization compared to the two other areas.

Nonetheless, the costs of these three formulated feeds of $O$. niloticus juveniles' nutritional requirement that was adapted ranged between 0.43 and $0.52 \mathrm{USD} / \mathrm{kg}$ and were low compared to the costs of imported industrial commercial feeds (1.04-2.16 $\mathrm{USD} / \mathrm{kg}$ ) and were almost similar to industrial national commercial feeds $(0.42-0.51 \mathrm{USD} / \mathrm{kg})$ and the maximum costs of feeds sellers'

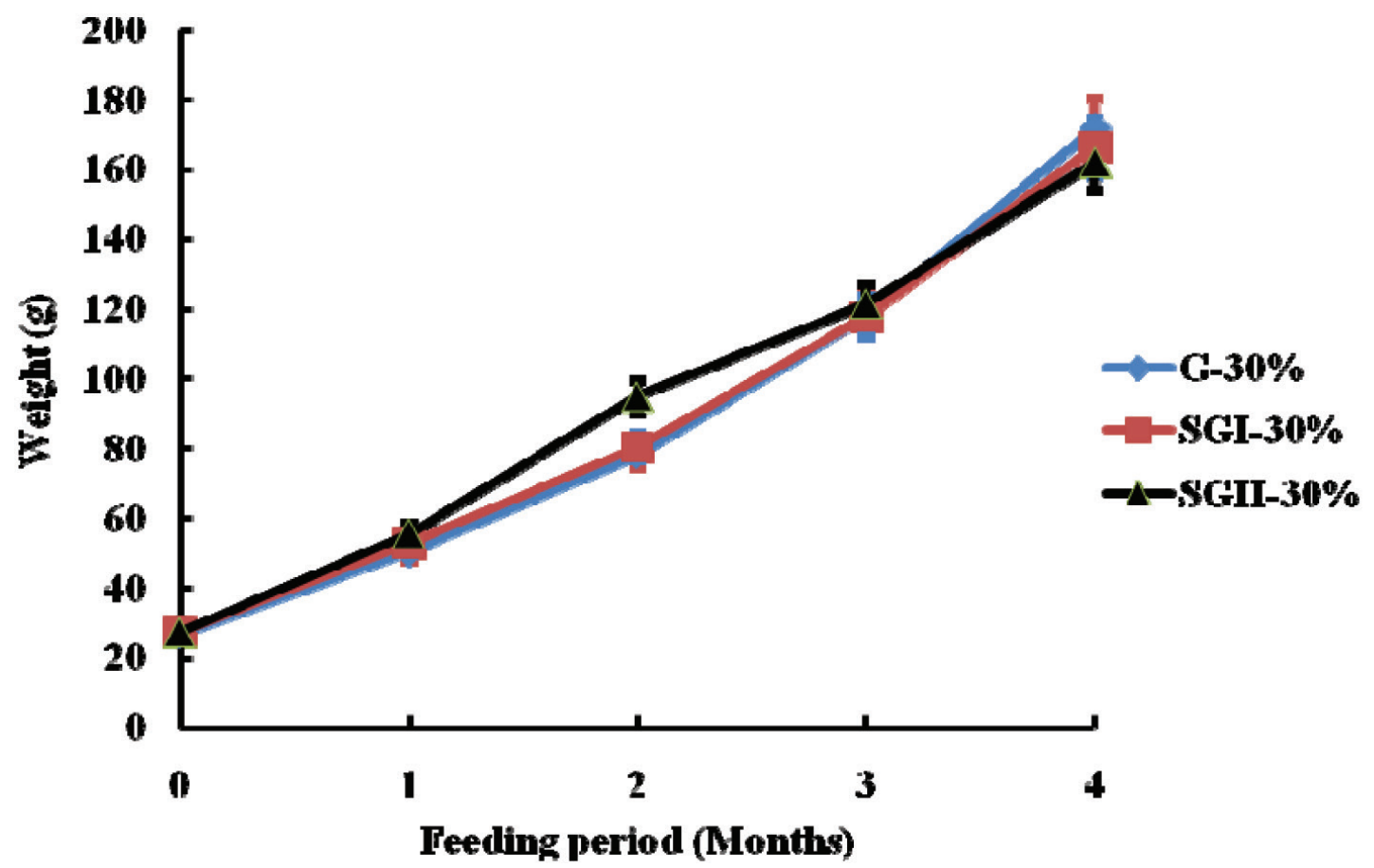

Figure 2: Growth evolution of $\mathrm{O}$. niloticus juveniles fed with feeds produced by fish farming agroecological area (Guinean zone; Sudano-Guinean area I = SG1; Sudano-Guinean area II) during 4 months. 
commercial feeds $(0.52 \mathrm{USD} / \mathrm{kg})$ and fish farmers' feeds $(0.47$ USD $/ \mathrm{kg}$ ) met in Côte d'Ivoire [11]. So the costs of the three feeds proposed calculated from retail prices of raw materials selling on the market and/or by the feeds sellers' feeds could be affordable for fish farmers in these three areas. Furthermore, the three simple composed feeds at $30 \%$ protein level had high nutritional quality than the feed sellers' commercial feeds, the majority of fish farmers' feeds and the agro-industrial byproduct used as fish feeds analyzed by [11]. Hence, the three feeds produced in this study offer the opportunity to improve availability and use of quality feeds for $O$. niloticus juveniles in the fish farming agroecological areas.

During the feeding trial, the water temperature of all the ponds ranged between $29.58 \pm 1.22$ and $29.92 \pm 1.140 \mathrm{C}$ and was revolved around $30 \mathrm{oC}$ reported as the optimal temperature of Tilapia Oreochromis niloticus rearing [32]. This resulted in advantage during the trial because the temperature is a control factor which plays a major role in fish metabolic regulation and can influence fish behavior and growth [33]. For high growth conditions of Tilapia O. niloticus in earthen ponds, [34] recommended a dissolved oxygen level ranged between 5 and $23 \mathrm{mg} / \mathrm{l}$. In this study, dissolved oxygen

Table 7: Mean values of growth performance and feed efficiency parameters of juveniles $O$. niloticus fed with the feeds produced by fish farming agroecological area (Guinean zone; Sudano-Guinean area I = SG1; SudanoGuinean area II) during 4 months.

\begin{tabular}{lccc} 
Parameters & \multicolumn{3}{c}{ Fish feeds } \\
& G-30\% & SGI-30\% & SGII-30\% \\
\hline Growth & & & \\
Initial body weight $(\mathrm{g})$ & $26.89 \pm 2.98^{\mathrm{a}}$ & $27.32 \pm 2.89^{\mathrm{a}}$ & $27.35 \pm 2.74^{\mathrm{a}}$ \\
Final body weight $(\mathrm{g})$ & $171.78 \pm 7.25^{\mathrm{a}}$ & $166.33 \pm 11.31^{\mathrm{a}}$ & $161.97 \pm 9.63^{\mathrm{a}}$ \\
Weight gain $(\mathrm{g})$ & $144.89 \pm 7.25^{\mathrm{a}}$ & $139.01 \pm 11.31^{\mathrm{a}}$ & $134.62 \pm 9.63^{\mathrm{a}}$ \\
Initial body length (cm) & $10.67 \pm 0.29^{\mathrm{a}}$ & $10.5 \pm 0.5^{\mathrm{a}}$ & $10.50 \pm 0.50^{\mathrm{a}}$ \\
Final body length (cm) & $20.93 \pm 0.48^{\mathrm{a}}$ & $20.36 \pm 0.57^{\mathrm{a}}$ & $20.76 \pm 0.48^{\mathrm{a}}$ \\
Length gain $(\mathrm{cm})$ & $10.26 \pm 0.56^{\mathrm{a}}$ & $9.86 \pm 0.93^{\mathrm{a}}$ & $10.26 \pm 0.98^{\mathrm{a}}$ \\
Daily weight gain $(\mathrm{g} /$ day) & $1.21 \pm 0.06^{\mathrm{a}}$ & $1.16 \pm 0.09^{\mathrm{a}}$ & $1.12 \pm 0.08^{\mathrm{a}}$ \\
Daily length gain $(\mathrm{cm} /$ day) & $0.09 \pm 0.01^{\mathrm{a}}$ & $0.08 \pm 0.01^{\mathrm{a}}$ & $0.09 \pm 0.01^{\mathrm{a}}$ \\
Specific growth rate (\%/day) & $1.54 \pm 0.03^{\mathrm{a}}$ & $1.50 \pm 0.06^{\mathrm{a}}$ & $1.48 \pm 0.05^{\mathrm{a}}$ \\
Survival rate $(\%)$ & 100 & 100 & $99.44 \pm 0.00^{\mathrm{a}}$ \\
Feed efficiency & & & \\
Feed conversion ratio & $2.85 \pm 0.14^{\mathrm{a}}$ & $2.87 \pm 0.23^{\mathrm{a}}$ & $2.88 \pm 0.21^{\mathrm{a}}$ \\
Protein efficiency ratio & $1.17 \pm 0.08^{\mathrm{a}}$ & $1.13 \pm 0.09^{\mathrm{a}}$ & $1.13 \pm 0.08^{\mathrm{a}}$ \\
\hline a,b,calphabetical letters on the same line show a significant difference among treatments at $p<0.05$
\end{tabular}

Table 8: Whole body composition of $O$. niloticus juveniles fed with feeds produced by fish farming agroecological area (Guinean zone; Sudano-Guinean area $\mathrm{I}=\mathrm{SG} 1$; Sudano-Guinean area II) during 4 months.

\begin{tabular}{llll} 
Parameters & \multicolumn{3}{c}{ Fish feeds } \\
& G-30\% & SGI-30\% & SGII-30\% \\
Moisture (\%) & $77.35 \pm 0.42^{\mathrm{b}}$ & $76.73 \pm 0.64^{\mathrm{ab}}$ & $75.57 \pm 1.11^{\mathrm{a}}$ \\
Crude protein (\%) & $20.26 \pm 1.13^{\mathrm{a}}$ & $19.83 \pm 1.10^{\mathrm{a}}$ & $20.78 \pm 1.05^{\mathrm{a}}$ \\
Crude lipid (\%) & $0.96 \pm 0.13^{\mathrm{a}}$ & $1.85 \pm 0.06^{\mathrm{b}}$ & $2.62 \pm 0.17^{\mathrm{c}}$ \\
Ash (\%) & $1.09 \pm 0.15^{\mathrm{a}}$ & $1.19 \pm 0.01^{\mathrm{a}}$ & $1.10 \pm 0.13^{\mathrm{a}}$ \\
Gross energy (kJ/g) & $5.18 \pm 0.06^{\mathrm{a}}$ & $5.43 \pm 0.02^{\mathrm{b}}$ & $5.96 \pm 0.23^{\mathrm{c}}$ \\
\hline
\end{tabular}

\footnotetext{
a,b, calphabetical letters on the same line show a significant difference among treatments at $p<0.05$.
}

values in ponds $(8.05 \pm 1.07-8.25 \pm 1.56 \mathrm{mg} / \mathrm{l})$ were within these reported values and show good oxygenation conditions of rearing ponds. Also, according to El-Sayed [35], O. niloticus can survive successfully and tolerate $\mathrm{pH}$ values recorded in these ponds (8.92 $\pm 0.88-9.62 \pm 0.74)$ which oscillated between recommended values ranged between 4 and 11. Otherwise, according to Abowei [36], natural waters have conductivity ranged between 20 and $1500 \mathrm{us} / \mathrm{cm}$. Conductivity values $(19.43 \pm 7.50-20.00 \pm 8.49 \mu \mathrm{s} /$ $\mathrm{cm}$ ) recorded in all pond waters influenced by the levels of total solids dissolved levels $(9.33 \pm 3.01-10.50 \pm 4.89)$ were within the conductivity values of natural waters $(20-1500 \mathrm{us} / \mathrm{cm})$. Similarly, the total solids dissolved values recorded in pond waters were under to the limit recommended at $500 \mathrm{mg} / 1$ [37]. In view of these comparisons, the degradation activities of organic matter and the mineral discharges from three feeds used by fish did not influence negatively the physicochemical characteristics of the water in the earthen ponds. In fact, all water physicochemical parameters data recorded showed the good growth conditions of $\mathrm{O}$. niloticus juveniles during the feeding trial.

Growths of the three groups of $O$. niloticus juveniles fed with the feeds formulated were similar despite the significant difference observed in some nutritional parameters (moisture, lipid, fiber, ash, carbohydrate, gross energy, and protein/energy) of feeds. Also, values of feeds efficiency recorded during the feeding trial were not influenced by the quality of feeds, and, the survival rates at the end of the feeding trial were high $(99.44 \%$ and $100 \%)$. These results proffer the opportunity to use low-cost local fish meal rich in ash as a protein source in juveniles $O$. niloticus feeds formulations. Likewise, cashewnut oil cake can be used as a lipid source and an additional protein and carbohydrate source in $O$. niloticus local quality feeds formulations. Similar growth results show also the opportunity of fish farmers to use the simply composed $30 \%$ protein fish feed with only three ingredients (SGI-30\%) as high-quality feed for O. niloticus juveniles rearing.

Daily weight gain values recorded from $O$. niloticus fed with the formulated feeds (G-30\%, SGI-30\%, and SGII-30\%), which ranged between $1.12 \pm 0.08$ and $1.21 \pm 0.06 \mathrm{~g} /$ day, were higher than those obtained $(0.35 \pm 0.01 \mathrm{~g} / \mathrm{d})$ by Oumer [38] with $O$. niloticus juveniles fed with $30 \%$ protein content feed in concrete ponds and further higher than those $(0.89 \mathrm{~g} / \mathrm{d})$ of Opiyo et al. [39] recorded with the same fish fed in earthen ponds with $32.7 \%$ protein level of feed. Also, the daily weight gain values recorded with the feeds proposed in this study were higher than $0.86 \pm$ $0.20 \mathrm{~g} / \mathrm{j}$ reported by Sumagaysay-Chavoso [40] and were almost equal to the value of $1.5 \mathrm{~g} / \mathrm{d}$ reported as reference growth value in intensive rearing system of $O$. niloticus juveniles by FAO [41]. In the same trend, specific growth rate values recorded in this study $(1.48 \pm 0.05-1.54 \pm 0.03 \% / \mathrm{d})$ were in the same order as those of $1.17 \pm 0.06-1.49 \pm 0.02 \% / \mathrm{d}$ reported by Abarike et al. [42] from O. niloticus fed with $30 \%$ protein in out-door hapas, and higher than $1.01 \pm 0.02$ and $1.25 \pm 0.02 \% / \mathrm{d}$ recorded from the same fish by Opiyo et al. [39] with a commercial $32.7 \%$ protein level feed in earthen pond rearing during 6 months.

Concerning the efficiency of the feeds used, feed conversion ratio values recorded with fish fed with feeds produced varied between $2.85 \pm 0.14$ and $2.88 \pm 0.21$ and were similar to those $(2.83-2.87)$ 
recorded by Ghozlan et al. $[43,44]$ with juvenile $O$. niloticus fed with floating industrial commercial feed at $25 \%$ crude protein supplemented in vitamin and mineral premix during 6 months in the earthen ponds. Otherwise, feed conversion ratio (FCR) is an important indicator of the quality of fish feed, also, low FCR indicates better utilization of the fish feed [45]. Hence, the feeds conversion ratio values that recorded $(2.85 \pm 0.14-2.88 \pm 0.21)$ lower or equal to 3 indicate the good use of all feeds by fish.

Compared results of daily weight gain, survival rate, specific growth rate, and feed conversion ratio with the previous research data show the competitiveness of these three feeds formulated at $30 \%$ protein level adapted to the $O$. niloticus juveniles rearing in the earthen ponds. These results could be due to the fact that these three feeds formulated at $30 \%$ protein proposed at low cost with the accessible raw materials in the three agroecological fish farming areas met well the essential nutritional needs for O. niloticus growth at this stage $[29,31,46]$. Results show the possibility of fish farmers in these areas to make simple composed feeds adapted to the growth of $O$. niloticus juveniles to improve growth and to reduce the time of merchant fish production. Results present also an opportunity to improve the availability of competitive quality fish feeds in the high concentration of fish farmers' areas in Côte d'Ivoire.

Whole body protein composition of fish fed was not influenced by the quality of feed used. This result must be due to the fact that at $O$. niloticus, whole body protein composition is not affected by the proximate composition of feeds when feeds used are the same protein content $[24,47]$. The increase of crude lipid and gross energy from $O$. niloticus species with high levels of dietary lipid observed, it's already well documented $[25,48,49]$. In fact, $O$. niloticus is unable to use dietary lipid and energy to improve feed efficiency and fish growth as observed from some catfish, so it accumulates dietary lipid in its carcass [50,51]. The similar ash levels recorded in whole body composition of $O$. niloticus independently to the feed used confirms the releasing of the excess of minerals and ash to feed G-30\% into the water by fish.

\section{CONCLUSION}

The three composed feeds based on the available feedstuffs in three agroecological areas in Côte d'Ivoire were competitive to improve Oreochromis niloticus juveniles growth. Variation of raw materials used influenced biochemical composition of feeds formulated, but $O$. niloticus used these feeds for similar growth performance, feed utilization, and whole body protein content. These feeds proffer the opportunity to improve the availability of low-cost local quality feeds for $O$. niloticus juveniles rearing in the high concentration areas of fish farmers in Côte d'Ivoire.

\section{ACKNOWLEDGMENTS}

This work is a part of the framework of the PAFARCI (project to support the recovery of agricultural sectors in Côte d'Ivoire) project funded by the FIRCA (national inter-professional fund for research and agricultural council). Authors express their gratitude to the FIRCA and also thank feed sellers feeds and fish farmers for their help in this work. Authors also accord thanks to the
Ivorian Association of Agronomic Sciences (AISA) for the good management of the funds for this project.

\section{REFERENCES}

1. Mozaffarian D, Rimm EB. Fish intake, contaminants, and human health: evaluating the risks and the benefits. J Am Med Assoc 2006;296:1885-99.

2. Weichselbaum E, Coe S, Buttriss J, Stanner S. Fish in the diet: a review. Nutr Bull 2013;38:128-77.

3. AU-IBAR. An industry assessment of Tilapia farming in Egypt. African Union-Inter-African Bureau for Animal Resources, Nairobi, Kenya, 2013.

4. FAO. Fisheries and Aquaculture Information and Statistics Service, 2014. Available via http://www.fao.org/figis/servlet/ SQServlet? $\mathrm{ds}=$ Aquaculture \& $\mathrm{k} 1=$ COUNTRY \&k1 $=1 \& \mathrm{k} 1 \mathrm{~s}=$ 107\&outtype $=\mathrm{html}$ (Accessed 11 August 2014).

5. Yao AH, Koumi AR, Atsé BC, Kouamélan EP. Etat des connaissances sur la pisciculture en Côte d'Ivoire. Agron Afr 2017;29(3):227-44.

6. Hem S, Legendre M, Trebaol L, Cissé A, Otémé Z, Moreau Y. L'aquaculture lagunaire. In: Durand JR, Dufour P, Guiral D, Zabi SDF (eds.). Environnement et Ressources Aquatiques de Côte d'Ivoire: Les Milieux Lagunaires, Tome II, ORSTOM, Paris, France,, pp 455-505, 1994.

7. Liti DM, Cherop L, Mungitti J, Chorn L. Growth and economic performance of Nile tilapia (Oreochromis niloticus) fed on two formulated diets and two locally available feeds in fertilized ponds. Aquac Res 2005;36:746-52.

8. Koumi AR, Kimou BN, Ouattara IN, Koffi KM, Atsé BC, Kouamé LP. Les aliments utilisés en pisciculture semi intensive en Côte d'Ivoire et leur productivité. Tropicultura 2016;34(3):286-99.

9. Brechbühl A. The future of pisciculture in southern Côte d'Ivoire. Bachelor thesis, ETH, SC/nat CSRS, Zürish/Abidjan, p 50, 2009.

10. Toily KNB. La filière piscicole en Côte d'Ivoire: Cas des régions d'Abidjan, Agboville et Aboisso. Thèse de Doctorat de l'Ecole InterEtats des Sciences et Médecine Vétérinaires (E.I.S.M.V.) de Dakar, Sénégal, p 94, 2009.

11. Koumi AR, Kimou BN, Atsé BC, Ouattara IN, Kouamé LP. Fish feeds used in Côte d'Ivoire: Nature, quality, use and productivity. Asian J Agric Food Sci 2015;3(2):225-36.

12. Koumi RA, Kimou NB, Ouattara IN, Atsé CB, Kouamé PL. Utilization of fish feeds by Côte d'Ivoire fish farmers and its influence on the quantitative competitive commercial fish production. Int $\mathrm{J}$ Biochem Res Rev 2017;19(3):1-13.

13. Jamu DM, Ayinla OA. Potential for the development of Aquaculture in Africa. NAGA 2003;26:9-13.

14. Gabriel UU, Akinrotimi OA, Bekibele DO, Onunkwo DN, Anyanwu PE, Locally produced fish feed: potentials for aquaculture development in sub-Saharan Africa. Afr J Agric Res 2007;2:287-95.

15. Lacroix E. Pisciculture en zone tropicale. GFA terra systems, Hamburg, Germany, 2004

16. Lazard J. La pisciculture des tilapias. Cahiers Agric 2009;18:174-82; doi:10.1684/agr.2009.0305

17. Liti DM, Mugo RM, Munguti JM, Waidbacher H. Growth and economic performance of Nile tilapia (Oreochromis niloticus L.) fed on three brans (maize, wheat and rice) in fertilized ponds. Aquac Nutr 2006;12:239-45.

18. Hernández C, Olvera-Novoa MA, Hardy RW, Hermosillo A, Reyes C, González B. Complete replacement of fish meal by porcine and poultry by-product meals in practical diets for fingerling Nile Tilapia Oreochromis niloticus: digestibility and growth performance. Aquac Nutr 2010;16:44-53.

19. Workagegn KB, Ababboa ED, Yimer GT, Amare TA. Growth performance of the Nile Tilapia (Oreochromis niloticus L.) fed different types of diets formulated from varieties of feed ingredients. J Aquac Res Dev 2014;5(3):1-4. 
20. Obirikorang KA, Amisah S, Agbo NW, Adjei-Boateng D, Adjei NG, Skov PV. Evaluation of locally-available agroindustrial byproducts as partial replacements to fishmeal in diets for Nile Tilapia (Oreochromis niloticus) production in Ghana. J Anim Res Nutr 2015;1(1:2):1-9.

21. Bamba Y, Ouattara A, Gourène, G. Production d'alevins de tilapia (Oreochromis niloticus l., 1758) nourris avec des sousproduits agricoles, sans adjonction de farine de poisson. Agron Afr 2007;19(2):211-21.

22. Bamba Y, Ouattara A, Da Costa KS, Gourène G. Production de Oreochromis niloticus avec des aliments à base de sous-produits agricoles. Sci Nat 2008;5(1):89-99.

23. Koumi AR, Atsé BC, Kouamé LP. Utilization of soya protein as an alternative protein source in Oreochromis niloticus diet: growth performance, feed utilization, proximate composition and organoleptic characteristics. Afr J Biotechnol 2009;8(1):091-7.

24. Koumi AR, Koffi KM, Atsé BC, Kouamé LP. Growth, feed efficiency and carcass mineral composition of Heterobranchus longifilis, Oreochromis niloticus and Sarotherodon melanotheron juveniles fed different dietary levels of soybean meal-based diets. Afr J Biotechnol 2011;10(66):14990-8; doi:10.5897/ajb10.1449.ISSN 1684-5315

25. MINESUDD (Ministère de l'Environnement de la Salubrité Urbaine et du Développement Durable). Communication-pays: L'agriculture intelligente face au climat en Côte d'Ivoire: Etat des lieux et besoins d'appui pour mieux intégrer l'agriculture intelligente face au climat (AIC) dans le programme national d'investissement agricole (PNIA). MINESUDD, Abidjan, Côte d'Ivoire, 2014.

26. AOAC. Official methods of analysis. 16th edition, AOAC, Arlington, Virginia, 1995.

27. AOAC. Metals and others elements. Association of Analytical Chemist, Arlington, Virginia, 2003.

28. Steffens W. Principes of fish nutrition, aquaculture and Fisheries support. Ellis Horwood, United Kingdom, 1989.

29. Guillaume J, Kaushik S, Bergot P, Metailler R. Nutrition et alimentation des poissons et crustacés. INRA, Paris, France, 1999.

30. Pouomogne V, Takam G, Pouomogne, J. A preliminary evaluation of cacao husks in practical diets for juvenile Nile tilapia (Oreochromis niloticus). Aquaculture 1997;156(3-4):211-9.

31. Lazard J. Le tilapia. Cirad, Paris France, 2007. Available via http:// www.aquatrop.cirad.fr

32. Xie S, Zheng K, Chen J, Zhang Z, Zhu X, Yang Y. Effect of water temperature on energy budget of Nile tilapia Oreochromis niloticus. Aquac Nutr 2011;17:e683-90.

33. Jun Q, Pao X, Haizhen W, Ruiwei L, Hui W. Combined effect of temperature, salinity and density on the growth and feed utilization of Nile tilapia juveniles (Oreochromis niloticus). Aquac Res 2012;43:1344-56.

34. Makori AJ, Abuom PO, Kapiyo R. Effects of water physico-chemical parameters on tilapia (Oreochromis niloticus) growth in earthen ponds in Teso North Sub-County, Busia County. Fish Aquat Sci 2017;20:20 30 .

35. El-Sayed AFM. Tilapia culture. CABI Publishing, Oxfordshire, UK, 2006.

36. Abowei JFN. Salinity, dissolved oxygen, $\mathrm{pH}$ and surface water temperature conditions in Nkoro River, Niger Delta, Nigeria. Adv J Food Sci Technol 2010;2(1):16-21.

37. Ibrahim LA, Ramzy EM. Water quality and its impact on Tilapia zilli (Case Study) Qarun Lake-Egypt. Int Water Technol J 2013;3(4):170 91.

38. Oumer M, Mulugeta H, Temesgen G. Evaluation of formulated feed of plant and animal origin on the growth performance of Oreochromis niloticus in ponds, Ethiopia. Int J Fish Aquat Res 2016;1(1):16-21.
39. Opiyo MA, Githukia CM, Munguti JM, Charo-Karisa Harrison. Growth performance, carcass composition and profitability of Nile tilapia (Oreochromis niloticus L.) fed commercial and on-farm made fish feed in earthen ponds. Int J Fish Aquat Stud 2014;1(5):12-7.

40. Sumagaysay-Chavoso NS. Analysis of feeds and fertilizers for sustainable aquaculture development in Philippines. In: Hasan MR, Hecht T, Desilva SS, Taccon AGJ (eds.). Study and analysis of feeds and fertilizers for sustainable aquaculture development, FAO Fisheries Technical Paper. No. 497, FAO, Rome, Italy, pp 269-308, 2007.

41. FAO. Le Tilapia Oreochromis niloticus. Fiche FAO sur le tilapia du Nil, 2012. Available via www.sypague.com/elevage-aquaculture/ tilapia-oreochromis-niloticus/print.html

42. Abarike ED, Obodai EA, Attipoe FYK. Growth and economic performance of fingerlings of Oreochromis niloticus fed on different non-conventional feeds in out-door hapas at Akosombo in Ghana. Afr J Agric Res 2013;8(26):3384-91.

43. Ghozlan A, Zaki M, Gaber M, Nour A. Effect of different water sources on survival rate (\%) growth performance, feed utilization, fish yield, and economic evaluation on Nile Tilapia (Oreochromis niloticus) monosex reared in earthen ponds. Oceanogr Fish Open Access J 2017;4(1):1-7.

44. Ghozlan AA, Zaki MM, Gaber MM, Nour A. Effect of different water sources on survival rate (\%) growth performance, feed utilization, fish yield, and economic evaluation on Nile Tilapia (Oreochromis niloticus) monosex reared in earthen ponds. Oceanogr Fish Open Access J 2018;6(1):1-7.

45. Mugo-Bundi J, Oyoo-Okoth E, Ngugi CC, Manguya-Lusega D, Rasowo J, Chepkirui-Boit V. Utilization of Caridina nilotica (Roux) meal as a protein ingredient in feeds for Nile tilapia (Oreochromis niloticus). Aquac Res, 2013;1-12.

46. New MB. Feed and feeding of fish and shrimp. Rome, Italie: FAO, ADCP/REP. 1987.

47. Ofojekwu PC. Nutritive value of soybean in pelleted feed for Nile tilapia Oreochromis niloticus. J Aquac Sci 1993;8:61-5.

48. Abdelghany AE. Partial and complete replacement of fish meal with gambusia meal in diets for red tilapia Oreochromis niloticus x $O$. mossambicus. Aquac Nutr 2003;9:145-54.

49. Goda AMA-S, Wafa ME, El-Haroun ER, Chowdhury MAK. Growth performance and feed utilization of Nile tilapia Oreochromis niloticus (Linnaeus, 1758) and tilapia galilae Sarotherodon galilaeus (Linnaeus, 1758) fingerlings fed plant protein-based diets. Aquac Res 2007;38:827-37.

50. Company R, Calduch JA, Perez-Sanchez J, Kaushik J. Protein sparing effect of dietary lipids in common dentex (entex Dentex d): a comparative study and protein utilization in juveniles sea bass. Dicentrarchus labrax. Aquaculture 1999;72:115-29.

51. Babaloba TOO, Apata DF. Effects of dietary and lipid levels on growth performance and body composition of African catfish Heterobranchus longifilis (Valenciennes, 1840) fingerlings. Asian J Anim Vet Adv 2006;5(12):1073-9.

\section{How to cite this article:}

Kouadio EPL, Koumi AR, Gonnety TJ, Atsé BC, Kouamé LP. Comparative study of three locally available feeds on the growth and nutritional quality of Oreochromis niloticus juveniles. J Appl Biol Biotech 2019;7(05):83-91. 